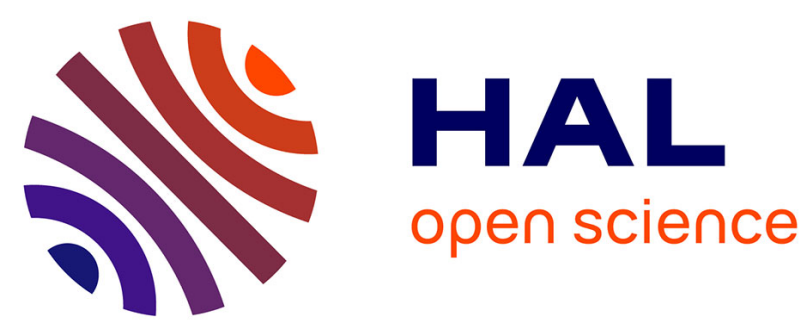

\title{
A new way of seeing pulses: preliminary results of geometric morphometric analyses of Iron Age seeds from the site of La Font de la Canya (Barcelona, Spain)
}

Chavarri Miguel Tarongi, Bonhomme Vincent, Evin Allowen, Ivorra Sarah, Reyes Dani López, Martínez Natàlia Alonso, Bouby Laurent

\section{To cite this version:}

Chavarri Miguel Tarongi, Bonhomme Vincent, Evin Allowen, Ivorra Sarah, Reyes Dani López, et al.. A new way of seeing pulses: preliminary results of geometric morphometric analyses of Iron Age seeds from the site of La Font de la Canya (Barcelona, Spain). Vegetation History and Archaeobotany, 2020, 10.1007/s00334-020-00801-2 . hal-03097330

\section{HAL Id: hal-03097330 \\ https://hal.science/hal-03097330}

Submitted on 5 Jan 2021

HAL is a multi-disciplinary open access archive for the deposit and dissemination of scientific research documents, whether they are published or not. The documents may come from teaching and research institutions in France or abroad, or from public or private research centers.
L'archive ouverte pluridisciplinaire HAL, est destinée au dépôt et à la diffusion de documents scientifiques de niveau recherche, publiés ou non, émanant des établissements d'enseignement et de recherche français ou étrangers, des laboratoires publics ou privés. 


\title{
A new way of seeing pulses: preliminary results of geometric morphometric analyses of Iron Age seeds from the site of La Font de la Canya (Barcelona, Spain)
}

\author{
Miguel Tarongi Chavarri ${ }^{1}$, Vincent Bonhomme ${ }^{2}$, Allowen Evin ${ }^{2}$, Sarah \\ IVORRA $^{2}$, DANI LÓPEZ REYES ${ }^{3}$, NATÀLIA ALONSO MARTÍNEZ ${ }^{1}$, LAURENT BOUBY ${ }^{2}$ \\ ${ }^{1}$ GIP, 3DPatrimoni, Departament d'Història, Fac. de Lletres, INDEST, \\ Universitat de Lleida, Pl. Victor Siurana, 1, 25003 Lleida, Catalonia, Spain, e- \\ mail:m.tarongi@historia.udl.cat
}

${ }^{2}$ ISEM - UMR 5554, Université Montpellier C/C 065, CNRS, EPHE, IRD, Place Eugène Bataillon, 34095 Montpellier cedex 05, France

${ }^{3}$ ArqueoVitis sccl. Camí de Sant Pere d'Avinyó, s/n 08973 Avinyonet del Penedès. Barcelona. Spain

\begin{abstract}
This study applied size and shape analyses through traditional and geometric morphometrics to quantify the differences between three taxa: Lathyrus sativus (grass pea), Lens culinaris (lentil) and Vicia faba (broad bean). This analysis represents a pilot study in view of a wider future application of this technique to identify the role of legumes throughout the Western Mediterranean in the Bronze and Iron Ages. Here, we quantify the morphological differences of seed species from the site of La Font de la Canya (Catalonia, Spain), an Iron Age (625-150 BC) centre of storage and trade which delivered a vast assemblage of cereal, fruit and legume remains. Our results reveal that seed outline analyses have a greater potential of prediction than length measurements. The combination of the two, however, leads to even more precise predictions. Moreover, the quantitative differences between the lentils of the different samples confirm the potential of these analyses to further identify intra-species morphotypes.
\end{abstract}

Keywords Legumes - Seed Outline · Distance measurements $\cdot$ Lens culinaris · Lathyrus sativus $\cdot$ Vicia faba

\section{Introduction}

Along with cereals, legumes are one of the most important resources for human consumption due both to their large number of cultivated species and their nutritional properties. The domestication of the first cereals and legumes took 
place simultaneously during the Preceramic Neolithic (9000-8000 cal BC) of Southwest Asia (Zohary and Hopf 1973; Zohary et al. 2012). Kislev and BarYosef (1988) suggested that legumes were cultivated even earlier, as the processes for their preparation for consumption is straightforward, contrary to cereals. Ethnographic and archaeological data nonetheless reveal that legumes were always secondary to cereals throughout the Mediterranean Basin. This could explain why they have been relegated in archaeobotanical literature to a secondary role behind cereals (Tarongi et al. 2020).

The earliest cultivation of legumes in the Northeast of the Iberian Peninsula is evidenced by charred seeds of Vicia faba (broad bean) and Pisum sativum (pea) at the sites of La Draga and the Caserna de Sant Pau (Catalonia) in an Early Neolithic context (5400-5000 cal BC). The earliest Lens culinaris (lentil) identified in this region are from a late phase of the Early Neolithic (5000-4500 cal BC) of the site of Plansallosa. Other species such as Vicia ervilia (bitter vetch) and $V$. sativa (common vetch) are identified since the early phases of the Middle Neolithic (4500-4000 cal BC). The cultivation of this last species, nonetheless, is not assured due to the modest numbers of seeds encountered in the sites. Throughout the remaining part of the Neolithic these species are poorly represented (Antolín 2016). A slight and progressive increase of frequency of legumes took place later in the Bronze Age (2200-700 BC) in the study area. This phase also saw the appearance of the earliest regional evidence of Lathyrus sativus/cicera (grass/red pea) (Albizuri et al. 2011).

The frequency and number of seeds of cultivated legume species increased even more during the First Iron Age (700-575 BC). Concentrations of pulses appear for the first time in Catalan sites such as Font de la Canya (López et al. 2015) and Sant Jaume Mas d'en Serra (López et al. 2011; López 2016). They are represented by large numbers of lentils, grass peas and broad beans at the first site and grass peas at the second. During the Iberian Period these high prevalences persist, as evidenced by a concentration of broad beans at Puig de Sant Andreu de Ullastret (Buxó 1997), as well as peas, grass peas and vetches at Mas Castellar de Pontós (Canal 2002), grass peas at Les Malesses (López 2006) and lentils at Font de la Canya (López 2004).

The increase in taxa frequency and in the number of legume seeds during the Bronze and Iron Ages leads to speculation as to the role they played in changes of 
the agricultural system. This increase could be linked to extensive cultivation, which could be related to the introduction of crop rotation through this period. The occurrence of grass pea may be indicative of the cultivation of less fertile lands, since this species can easily grow in poor, dry and uneven soils (Sarpaki 1992; Peña Chocarro and Zapata 1999). All these questions point to the necessity of studying in more detail the role of legumes during the Iron Age.

A characteristic of legumes, and the Fabaceae family as a whole, is the great interspecific morphological variability of their seeds. For instance, the position that a seed occupies in the pod can largely modify its shape. Also, the large number of genera and species in Fabaceae and the recognized variability within and between species of this family complicates their taxonomic identification. In spite of there being studies on how to identify these species through their seeds at the level of the genus (Kirkbride et al. 2003) and species (Lersten and Gunn 1982), these do not necessarily serve to identify archaeobotanical seeds since they are based on the testa, hilum and lens, parts of the seeds that are rarely preserved among charred archaeological remains.

Moreover, although legumes have received less attention than cereals and certain fruit, there are nonetheless notable studies of pulses: Kislev (1989), Butler (1990, 1992), Jones (1992), Sarpaki (1992), Peña-Chocarro and Zapata (1999), Fuller and Harvey (2006), Valamoti et al. (2011), Caracuta et al. (2015, 2017), Filatova et al. (2019) and Tarongi et al. (2020). Yet, as opposed to the studies of cereals (notably the data compiled by Jacomet 2006), there is no systematic listing of the criteria serving to identify legumes. This dearth of points of reference is even evidenced by a lack of terminology for describing and orienting archaeological seeds when photographing them. This absence of consensus was in fact discussed at the 18th Conference of the International Workgroup for Palaeoethnobotany celebrated in Lecce in 2019.

In this study, geometric morphometry has been applied to the archaeological legumes of Font de la Canya in order to investigate their potentiality for establishing quantitative differences between the shape of different species and samples. The choice of this technique stems from the significant breakthrough obtained with other archaeological taxa of cereals (Bonhomme et al. 2017) such as barley (Ros et al. 2014) and millet (García-Granero et al. 2016), and with fruit taxa such as olives (Terral et al. 2004), grapes (Terral et al. 2010; Pagnoux et al. 
2015; Ucchesu et al. 2015; Bouby et al. 2016), dates (Terral et al. 2012) and melons (Sabato et al. 2017). This study uses these morphometric approaches and examines for the first time only well-preserved archaeological seeds from the site of Font de la Canya (Fig. 1) in the Northeast of the Iberian Peninsula. Some investigations analyse the shape of the current legume seeds through different techniques. Cervantes et al (2019) quantitatively calculated the area of overlap between the seeds of some legume species, obtaining the $\mathrm{J}$ index (common area divided by the total area of both images) and the circularity. Other studies obtain photographs of lentils to obtain the volume and surface area of two varieties of lentils (Firatligil-Durmuş et al. 2008) or to obtain size ranges for subsequent marketing (LeMasurier et al. 2014). However, the use of these techniques on archaeological individuals does not seem to be very effective since it compares the seeds with predetermined shapes and uses a single view of each one.

The main objective of this study is to prove the efficiency of the application of geometric morphometry to archaeological seeds from different legume species, determining if it is possible to quantify the differences between them. To verify its potential, we decided to study the seeds of pulses from a site whose species have significant morphological differences. Once the efficiency of this method has been verified, future studies will be carried out on a larger taxonomic, spatial and chronological scale. Another objective of this article is to verify the differences in shape and size of the same species in the different phases of the same site through geometric morphometry. This technique requires the complete outline of the seeds, so individuals in a poor state of conservation cannot be used. This study is part of a research project led by the University of Lleida on the wider role of legumes in agri-food practices in the western Mediterranean throughout the second and first millennium BC.

\section{Materials and methods}

\section{Archaeological materials}

Due to the favourable conditions of preservation (charring) of the archaeological seeds of Font de la Canya, optical identification was straightforward (López 2004), always taking into account that carbonization leads to an unequal reduction 
in length, width and thickness of the seeds, producing deformations with respect to current individuals (Kislev and Rosenzweig 1989; Braadbaart et al. 2004; Caracuta et al. 2015). Grass peas identified in prior research as Lathyrus sativus (López 2004) have been classified as Lathyrus sativus/cicera in this study, as the smaller current varieties of $L$. sativus may overlap with $L$. cicera, a similarity that is more pronounced in archaeological seeds (Mahler-Slasky and Kislev 2010). The only parameter serving to clearly differentiate them is the testa (Chernoff et al. 1992), which is most often not preserved after carbonisation.

The site of Font de la Canya can be broken down into three well-defined chronological phases: Early Iron Age (625-550 BC), Early Iberian period (550400 BC) Middle Iberian period (400-200 BC) (López et al. 2015). The site's features are dominated by about 1,000 underground silos. Although the site reveals no evidence of dwellings, there are certain buildings designed for storage or craftwork such as metallurgy (López et al. 2015). All of the archaeobotanical remains come from the silos, with cereals standing out above the rest of the taxa, although legumes and grape seeds are also of great importance. These Early Iron Age grape pips and pedicels are in fact the earliest evidence of viticulture in the Northeast of the Iberian Peninsula (López et al. 2015).

Only assemblages containing more than 10 seeds from any cultivated leguminous species were retained for the study. Additionally, only the taxa with more than 10 individuals in the whole settlement were retained for the study. The final dataset gathered 1,403 seeds of three taxa: Lens culinaris ( $=1082)$, Lathyrus sativus/cicera $(\mathrm{N}=181)$ and Vicia faba $(\mathrm{N}=140)$. These seeds originate from 16 different stratigraphic units, 11 from the Early Iron Age, 1 from the Early Iberian period, and 4 from the Middle Iberian period (Table 1). All were collected in secondary non-domestic silo filling contexts. Their combination with finds of other archaeological materials proves they are not in situ but part of waste that ultimately filled the structures (López 2004). 984 lentils, 173 grass peas and 139 broad beans are from the Early Iron Age. 18 lentils are from Middle Iberian period and 80 lentils, 8 grass peas and 1 broad bean are from the Early Iberian period. 


\section{Data acquisition}

\section{Photography}

The geometric morphometric analysis was carried out on two orthogonal photographs of each seed. The ventral view was defined as that where the radicle and the hilum (when conserved) occupy the centre of the image. For the purposes of this study, the radicle is placed so that it occupies the top of the image with the hilum (or its scar) also to the top. The lateral view is orthogonal to the first (Fig.

2). These criteria in ventral view, with the exception of a downward orientation of the radicle, were discussed during the 18th IWGP Conference (Lecce) and serve in certain publications (Caracuta et al. 2014, 2015, 2017).

Each seed was manually positioned, photographed, and two landmarks were sampled. These were oriented and photographed at the Institute of Evolution Sciences of Montpellier (France) with an Olympus SZ-ET stethoscopestereoscopic microscope and at the University of Lleida (Spain) with a Motic SMZ 168 microscope. The total margin of error, chiefly parallax distortions and landmark positioning, as well as potential variations due using two different types of equipment, was tested on groups of five seeds of differing species.

\section{Distance measurements and outline shape analyses}

We quantified differences between the three species using: 1) traditional morphometrics with distance measurements, 2) geometric morphometrics using outline analysis, and 3) the combination of these two. The values of distance measurements were measured from the photographs (Fig. 2) with Image J v. 1.50 software. Length on the ventral view corresponds to the Feret's diameter of the longitudinal axis; width corresponds to the Feret's diameter of the transversal axis; thickness corresponds to the Feret's diameter of the longitudinal axis of the lateral view (Fig. 2). All distance measurements were log-transformed. Outline analyses were performed on the different seeds using elliptical Fourier transforms (hereon abbreviated to EFT). All the photographs were processed with Image $\mathrm{J}$ to remove the background. In the ventral view the two landmarks correspond to the intersection between the contour and the suture between the two cotyledons. In the lateral view, they are equivalent to the upper and lower ends of 
the seed (Fig. 3). Finally, the image was converted into a binary mask (black and white).

The (x; y) coordinates of the outline (Fig. 3), were obtained with the Momocs package in the $\mathrm{R}$ environment (Bonhomme et al. 2014; R Core Team). The next step consisted of normalising (centre, scale and homogenise the first point) the outlines using the two landmarks.

EFT turns outline coordinates into morphometric coefficients associated with the progressive decomposition of the outline into a series of trigonometric functions called harmonics $(\mathrm{H})$. Each harmonic was associated with four coefficients, (two for $\mathrm{x}-$, and two for $\mathrm{y}$ - coordinates). Here, eight harmonics led to an accurate description of the shape and we thus used 32 morphometric coefficients for the shape description.

\section{Statistical analysis}

The differences in distance measurements and outline coefficients were explored using Principal Component Analysis (PCA) and tested with Multiple Analysis of Variance (MANOVA). The differences between species and assemblages were modelled using Linear Discriminant Analyses (LDA) paired with leave-one-out cross-validations. We considered two thresholds for posterior probabilities of seed classification, minimal (50\%) and very accurate (90\%) (Pagnoux et al. 2015). As the assemblages were unbalanced and since the variations in the number of seeds per group can affect the cross-validation results, a baseline was estimated using 1,000 permutations of balanced and re-sampled groups (Evin et al. 2013)

\section{Results}

\section{Testing for error in positioning of the seeds and landmarks}

We tested for errors in the positioning of the seeds and of the landmarks on the seeds using samples of 5 seeds of lentil and broad bean, each photographed twice in ISEM and twice in the University of Lleida, with different equipment. The computation of Analyses of Variance (ANOVA) yielded results with p-values ranging from 0.97 for lentils to 0.74 for broad beans, showing that the samples photographed at the two places cannot be distinguished. Therefore, human error in seed positioning does not provide significant differences. 


\section{Comparing the species by means of distance measurements}

Distance measurements of the three species clearly differed (MANOVA $\mathrm{P}<10^{-16}$ for length, width and thickness) (Table 2, Figs. 4 and 5). A Linear Discriminant Analysis (LDA) was carried out based on the distance variables. The mean precision accuracy of the Linear Discriminant analysis (LDA) obtained with 1,000 permutations is $94 \%$, far better than $33 \%$ of the random value of the three taxa. Leave-one-out cross validation allowed prediction of whether each seed belongs to the pattern established by the archaeobotanical identification (Fig. 5). The results range from $98 \%$ correct identification for lentils to $68 \%$ for broad beans (when only retaining the posterior probability $>90 \%$ ).

\section{Comparison of species using outline shape descriptors}

The Principal Component Analysis (PCA) carried out on the EFT coefficients only partly distinguishes the three species from each other along the PC1 axis. There is in fact a large overlap, particularly between Lathyrus sativus and Vicia faba (Fig. 5). The MANOVA test carried out applying all the components is $\mathrm{P}$ $<10^{-16}$

As in the previous case, the prediction of the probability of each seed belonging to each morphotype was calculated through the Leave-one-out cross validation paired with a LDA. The accuracy of the LDA obtained with 1,000 permutations is better than in the previous case, with an average of $97 \%$. The results of the classifications for each species are clearly superior to those based on distance measurements in the case of broad beans and grass peas (Table 3 ) and quite similar for lentils.

\section{Size and shape combination}

The third model combined length measurement and outline shape (Fig. 5). It is clear from the biplot that discrimination of the three species is greater when combined analysis is used. This is confirmed by the cross-validation of the LDA (Table 3). The accuracy of the LDA obtained with 1,000 permutations was the best of the three analyses, with an average of $98 \%$. 


\section{Chronological comparison of lentils}

Lentil is the only species represented in all three chronological phases of the site of La Font de la Canya, but its presence from one phase to another is disproportionate: 984 in the Early Iron Age (625-575 BC), 18 in the Early Iberian period (550-450 BC) and 80 in the Middle Iberian period (400-200 BC). In spite of the differences in sample size, it is possible to compare the individuals of the Early Iron Age with those of the Middle Iberian period as they each comprise enough individuals to offer reliable results.

Differences in length and outline shape descriptors can be observed between the seeds of the first and last phase (Fig. 6). The average length of the lentils in the Early Iron Age is $3.27 \mathrm{~mm}$ with a standard deviation of 0.42 while in Middle Iberian period it is $2.90 \mathrm{~mm}$ with a deviation of 0.37 . The mean widths are 2.01 $\mathrm{mm}$ with a deviation of 0.34 , and $1.59 \mathrm{~mm}$ with a deviation of 0.25 . The mean thicknesses, in turn, are $3.04 \mathrm{~mm}$ with a deviation of 0.42 , and $2.64 \mathrm{~mm}$ with a deviation of 0.34. A stronger difference in shape is observed when comparing the PC1 of the PCA carried out with on EFT coefficients.

The MANOVA $\left(\mathrm{P}<10^{-16}\right)$ confirms the differences between the chronological phases. The result of the ANOVA and the Tukey test in each variable, combine the Early Iron Age and the Early Iberian (in group a) and separate the Middle Iberian (in group b).

A similar analysis performed on shape descriptors and distance measurements but considering all the samples of lentils separately allowed the confirmation of the broad chronological differences and the identification of two Early Iron Age samples that coincide in size and shape with those of the Middle Iberian (Fig. 7). Two groups clearly stand out when subjected to Tukey's multiple comparison test. The first, made up of smaller seeds, comprises samples from the Middle Iberian and two from the Early Iron Age (0002, 0006, 0019 and 0020) while the second comprises seeds 20.2 \% larger, all from the Early Iron Age, except for one sample (0007) from the Early Iberian. 


\section{Discussion}

The three analyses performed confirm the existence of significant quantitative differences in size and shape between the three species. The outline shape analyses facilitate discrimination between species of similar size, such as grass pea and broad bean. The LDA of outline analyses with a posterior probability of $90 \%$ increases the accuracy of the prediction of grass peas and broad beans by $20.5 \%$ and $28.5 \%$ with respect to the distance measurements analysis. Lentils have similar results in both analyses. This therefore confirms that morphotypes (Fig. 8) gleaned from the values of outline shape are more accurate than those acquired through distance measurements. The values yielded by combining both analyses, in turn, increase the predictive model beyond 95\% for each species. In view of the results obtained in this study as well as in other species such as grapes (Terral et al. 2010), dates (Terral et al. 2012), olives (Terral et al. 2004; Netwon et al. 2014), barley (Ros et al. 2014; Wallace et al. 2018) and millet (García-Granero et al. 2016), the potential of geometric morphometrics to characterise and differentiate legume seeds is confirmed. Although the species studied do not present many taxonomic doubts in their identification, the great results obtained by combining biometric data and outline analysis, offers the possibility of applying this method to help identify seeds of questionable status. Distance measurements, although simple, are quite accurate for discrimination between species. Shape is nonetheless clearly superior but the best accuracies in identification were obtained by combining both. Distance measurements has traditionally served to distinguish between taxa such as Lathyrus sativus and Lathyrus cicera that are difficult to identify through optical observations alone (Buxó 1997). Distance measurements have also served to compare broad bean seeds from different chronological phases of the Chalcolithic and Bronze Age from various sites in Upper Andalusia (Montes-Moya 2014), or simply as a means to identify them or compare archaeological seeds with current species.

Geometric morphometric methods have proved their efficiency in characterization of seeds at infra-specific or varietal level for barley (Ros et al. 2014; Wallace et al. 2018) and grapes (Pagnoux et al. 2015) for example, a fact that opens the door of these types of analyses to legumes. The identification of two types of lentils shows how this method can establish quantitative differences in the shape and size of archaeological seeds of the same pulse species. In this paper, only the lentil 
assemblages of two chronological phases are numerous enough to allow reliable comparisons. Grass pea and bean seeds do not present variations in the different chronological phases or between the different samples, but this fact may be due to the smaller number of individuals of these species. The MANOVA tests carried out on distance measurements and on outline shape descriptors in lentil seeds confirm a significant difference between those of the Early Iron Age and the Middle Iberian period. However, these differences are not only chronological as two samples of the Early Iron Age are similar to those of the Middle Iberian. Unfortunately, the lack of grass peas and bean seeds among the samples in which these differences are observed does not permit determination whether this is the case for all three species.

The change in size and shape of the lentils from Font de la Canya seems to be unrelated to different steps in the domestication of the species. Although recent studies indicate that it was a slow process (Purugganan and Fuller 2011; Fuller et al. 2012, 2014) lentils were already domesticated when they arrived in the Iberian Peninsula in the sixth millennium BC. On the other hand, the changes observed during the domestication of lentils show an increase in size and not a reduction, as is the case of this site. The lack of a wild ancestor in the Western Mediterranean also rules out the possibility of hybrids.

This study advances two hypotheses, potential lines of future research, to explain the causality of these two groups. The first hypothesis is that differences in morphometrics could be evidence of the cultivation of different varieties of lentils at Font de la Canya. Several varieties of lentils are known today, which can be grouped into two taxonomic levels, microspermae and macrospermae, designated as subspecies by Barulina (1930) but identified today as groups of varieties (Cubero 1981; Toker et al. 2007). Microspermae are characterised by small seeds ( 2 to $4 \mathrm{~mm}$ in diameter) with pigmented testae, whereas macrospermae have larger seeds (6 to $9 \mathrm{~mm}$ ) with slightly pigmented testae (Mishra et al. 2007). Bearing in mind that the lengths in the current study correspond to the diameter of the seed and that lentils contract by about $20 \%$ when charred (Kislev and Rosenzweig 1989), the group of larger seeds would increase in mean length from 3.54 to $4.25 \mathrm{~mm}$, and the smallest from 2.82 to $3.48 \mathrm{~mm}$. The second group, in fact, could clearly fall within the range of the microspermae group while the first 
group could correspond to an intermediate level between the ranges of the two types.

Macrospermae offer higher yields in dry climates while the harvest of microspermae is higher in more humid environments (Ghassemi-Golezani et al. 2014). A phenotypic study of 101 traditional (yet unspecified) varieties in the Iberian Peninsula (Lázaro et al. 2001) has noted that varieties of heavier seeds, associated with macrospermae, predominate in drier regions while lighter seeds, presumably microspermae are common to humid areas. Hence, each of the groups of archaeological lentils from the site of Font de la Canya could belong to two different varieties of microspermae as the climate and size of the seeds at this site are adapted to this group. If these two varieties finally belong to the same type of group with equivalent ecological characteristics, their coexistence may be due to culinary preferences

The second hypothesis assumes that all the lentil seeds belong to the same variety, so the morphological changes are due to other factors, such as environmental conditions. Differences in size between lentil samples during the Early Iron Age may be due to the presence of lentil crops in irrigated and non-irrigated fields. Following the line of thought, the smaller lentils of the Middle Iberian period could correspond exclusively to non-irrigated crops. Irrigation, in particular, is interpreted as responsible for the change in size of broad bean seeds in Upper Andalusia during the Chalcolithic and Bronze Age (Montes-Moya 2014). Irrigation has also been associated with an increase in plant and pod size among lentils (Oweis et al. 2004). At the same time, extreme droughts affect the number of lentil flowers and pods, but not the size of the seeds (Shrestha et al. 2006), rejecting [negating?] the idea that the smallest ones occur in dry years. Plants reveal a preference for carbon $12\left(\mathrm{C}^{12}\right)$ over carbon $13\left(\mathrm{C}^{13}\right)$ in the process of photosynthesis, a fact bolstered by irrigation. It is possible to calculate the value of $\mathrm{C}^{13}$ of archaeological seeds through stable isotope analyses and compare the results with those of current seeds with known hydric values. In the case of broad beans, the most often studied species, the average of the current $\Delta^{13} \mathrm{C}$ values is 14.91 among dry crops and 16.67 among irrigated crops (Araus et al. 1997). In the western Mediterranean there are several cases such as that of three broad beans samples from the Chalcolithic and Bronze Age levels of the settlement of Las Eras del Alcazar (Jaén, Spain) with $\Delta 13 \mathrm{C}$ values of 17.06, 16.92 and 15.99. 
The first two are interpreted as having been cultivated in irrigated fields while the third was cultivated in dry lands (Mora 2017). Broad beans from the Southwest of the Iberian Peninsula also reveal evidence of irrigation (Araus et al. 1997). Hence it would be of great interest to carry out stable isotope analyses of the lentils from Font de la Canya, in combination with geo-morphometric analyses, to explore the question of ancient irrigation in this context. In order to improve this result, an experimental study could be carried out in which different varieties were grown with and without irrigation, quantifying the differences in the shapes of the seeds through geometric morphometry and isotope analysis. Finally, we could compare the results with the archaeological data and estimate whether the changes we have observed are due to irrigation.

\section{Conclusions}

In this study it has been possible to quantify the differences between archaeological legume seeds through two different methods, obtaining an increase in the accuracy of seed description of 20-30\% through geometric morphometrics rather than by size measurements alone. Combining both models helps to further improve this accuracy. Therefore, the results are very positive in inter- and intraspecific comparisons.

Moreover, this method validates the notion that two morphotypes of lentils were cultivated at Font de la Canya during respectively the site's Early Iron Age and Middle Iberian phases. The method should now be applied to a larger framework so as to explore the role of legumes in ancient communities throughout the Western Mediterranean Basin. Different morphotypes within the same species can also be linked to different taxonomic varieties or growing conditions. Another notion to explore is that irrigation can account for the differences in size and shape. In any case, this study offers new lines of future research and sheds light on legumes and their agricultural processes in past societies.

Acknowledgements This study was by funded by the projects HAR2016-78277-R (Ministerio de Economía y Competitividad, Spain) and SGR2017-1714 (Generalitat de Catalunya, Catalonia) of the University of Lleida. The original English draft of this paper was reviewed by T. J. Anderson. The Font de la Canya site is part of the project "El canvi sociocultural a la Cessetània oriental durant la protohistòria i l'època romana republicana" of the University of Barcelona. 


\section{References}

Antolín F (2016) Local, intensive and diverse? Early farmers and plant economy in the North-East of the Iberian Peninsula (5500-2300 cal BC). Barkhuis, Groningen

Araus J, Febrero A, Buxó R et al J (1997) Identification of Ancient Irrigation Practices based on the Carbon Isotope Discrimination of Plant Seeds: A Case Study from the South-East Iberian Peninsula. J Archaeol Sci 24:729-740

Albizuri S, Alonso N, López Cachero FJ (2011) Economia i canvi social a Catalunya durant l'edat del bronze i la primera edat del ferro. Arqueomediterrània12:11-36

Barulina E (1930) Lentils of the U.S.S.R and of the other countries. Bull Appl Bot Genet Plant Breeding Suppl 40:225-238

Bonhomme V, Picq S, Gaucherel C, Claude J (2014) “Momocs: Outline Analysis Using R”. J Stat Softw 56:1-24. https://doi.org/10.18637/jss.v056.i13

Bonhomme V, Forster E, Wallace M, Stillman E, Charles M, Jones G (2017) Identification of inter- and intraspecies variation in cereal grains through geometric morphometric analysis, and its resilience under experimental charring. J Archaeol Sci 86:60-67

Bouby L, Bonhomme V, Ivorra S et al (2016) Back from burn out: are experimentally charred grapevine pips too distorted to be characterized using morphometrics? Archaeol Anthropol Sci 10:943-954.

https://doi.org/10.1007/s12520-016-0425-x

Braadbaart F, Boon JJ, Veld H, David P, van Bergen PF (2004) Laboratory simulations of the transformation of peas as a result of heat treatment: changes of the physical and chemical properties. J Archaeol Sci 31:821833. https://doi.org/10.1016/j.jas.2003.12.001

Butler A (1990) Legumes in antiquity: a micromorphological investigation of seeds of the Vicieae. Dissertation, University College London, London

Butler A (1992) Pulse agronomy: Traditional systems and implications for early cultivation. In: AndersonGerfaud PC (ed) Préhistoire de l'agriculture: Nouvelles approches expérimentales et ethnographiques. Monographies due Centre de Recherches Archéologiques 6, Valbonne, pp 67-78

Buxó R (1997) Arqueología de las plantas: la explotación económica de las semillas y los frutos en el marco mediterráneo de la Península Ibérica. Crítica/Arqueología, Barcelona

Canal D (2002) L'explotació dels recursos vegetals: les anàlisis carpològiques. In: Pons E (ed) Mas Castellar de Pontós (Alt Empordà). Un complex arqueològic d'època ibèrica (excavacions 1990-1998). Sèrie

Monogràfica del MAC 21. Museu d'arqueologia de Catalunya, Girona, pp 443-476

Caracuta V, Barzilai O, Khalaily H et al (2015) The onset of faba bean farming in the Southern Levant. Sci Rep 5:14370. https://doi.org/10.1038/srep14370

Caracuta V, Vardi J, Paz Y, Boaretto E (2017) Farming legumes in the pre-pottery Neolithic: New discoveries from the site of Ahihud (Israel). PloS ONE 12: e0177859.

https://doi.org/10.1371/journal.pone.0177859

Caracuta V, Weiss E, van der Brink E, Liran R, Vardi J, Barzilai O (2014) From Natural Environment to Human Landscape: New Archaeobotanical Data from the Neolithic Site of Nahal Zippori 3, Lower Galilee. Neo-lithics 14:33-41 
Cervantes E, Saadaoui E, Tocino A, Martín-Gómez JJ (2019) Seed shape quantification in the model legumes: methods and applications. In: de Bruijn FJ (ed) The Model Legume Medicago truncatula. WileyBlackwell, Chichester, pp 92-98

Chernoff M, Plitman U, Kislev ME (1992) Characters and testa texture in species of the Vicieae: their taxonomic significance. Isr J Bot 41:167-186. https://doi.org/10.1080/0021213X.1992.10677225

Cubero JI (1981) Origin, taxonomy and domestication. In: Webb C, Hawtin G (eds) Lentils. CAB, Slough, pp $15-21$

Evin A, Cucchi T, Cardini A, Strand Vidarsdottir U, Larson G, Dobney K (2013) The long and winding road: Identifying pig domestication through molar size and shape. J Archaeol Sci 40:735-743.

https://doi.org/10.1016/j.jas.2012.08.005

Filatova S, Gyulai F, Kirleis W (2019) Environmental imposition or ancient farmers' choice? A study of the presence of "inferior" legumes in the Bronze Age Carpathian Basin (Hungary). In: Dal Corso M, Kirleis W, Kneisel J, Taylor N, Wieckowska-Lüth M, Zanon M (eds) How's life? Living Conditions in the 2nd and 1st Millennia BCE. Sidestone Press, Leiden, pp 57-84

Firatligil- Durmuş E, Šárka E, Bubník Z (2008) Image vision technology for the characterisation of shape and geometrical properties of two varieties of lentil grown in Turkey. Czech J Food Sci 26:109-116

Fuller DQ, Harvey EL (2006) The archaeobotany of Indian pulses: identification, processing and evidence for cultivation. Environ Archaeol 11:219-246. https://doi.org/10.1179/174963106x123232

Fuller DQ, Asouti E, Purugganan MD (2012) Cultivation as slow evolutionary entanglement: comparative data on rate and sequence of domestication. Veget Hist Archaeobot 21:131-145

Fuller DQ, Denham T, Arroyo-Kalin M et al (2014) Convergent evolution and parallelism in plant domestication revealed by an expanding archaeological record. Proc Natl Acad Sci USA 111:6,147-6,152

García-Granero JJ, Arias-Martorell J, Madella M, Lancelotti C (2016) Geometric morphometric analysis of Setaria italica (L.) P. Beauv. (foxtail millet) and Brachiaria ramosa (L.) Stapf. (browntop millet) and its implications for understanding the biogeography of small millets. Veget Hist Archaeobot 25:303-310. https://doi.org/10.1007/s00334-015-0541-z

Ghassemi-Golezani K, Chadordooz-Jeddi A, Zehtab-Salmasi S (2014) Effects of seed size and aging on field performance of lentil (Lens culinaris Medik.) under different irrigation treatments. Acta Agric Slovenica 103:158-166

Jacomet S (2006) Identification of cereal remains from archaeological sites, 2nd edn. IPAS, Basel University, Basel

Jones G (1992) Ancient and modern cultivation of Lathyrus ochrus (L.) DC. in the Greek islands. Annu Br School Athens 87:211-217. https://doi.org/10.1017/S0068245400015124

Kirkbride JH, Gunn CR, Weitzman AL (2003) Fruits and Seeds of Genera in the Subfamily Faboideae (Fabaceae). Agricultural Research Service, Washington DC

Kislev ME (1989) Origins of the cultivation of Lathyrus sativus and L. cicera (Fabaceae). Econ Bot 43:262270

Kislev ME, Bar-Yosef O (1988) The Legumes: The Earliest Domesticated Plants in the Near East? Curr Anthropol 29:175-179 
Kislev ME, Rosenzweig S (1989) Influence of experimental charring on seed dimensions of pulses. Acta Interdiscip Archaeol 7:143-157

Lázaro A, Ruiz M, de la Rosa L, Martín I (2001) Relationships between agro/morphological characters and climatic parameters in Spanish landraces of lentil (Lens culinaris Medik.). Genet Resour Crop Evol 48:239249. https://doi.org/10.1023/A:1011234126154

LeMasurier LS, Panozzo JF, Walker CK (2014) A digital image analysis method for assessment of lentil size traits. J Food Engineering 128:72-78

Lersten NR, Gunn CR (1982) Testa characters in the tribe Vicieae, with notes about tribes Abreae, Cicerae and Trifolieae (Fabaceae). Tech Bull U.S. Dept Agric 1667:1-40

López D (2004) Primers resultats arqueobotànics (llavors i fruïts) al jaciment protohistòric del Turó de la Font de la Canya (Avinyonet del Penedès). Revista d'arqueologia de Ponent 14:149-177

López D (2006) L’Explotaciódels recursos vegetals al jaciment ibèric de Les Maleses: primers resultats de l'estudi arqueobotànic de les llavors i fruits. Monte Catano 8:41-70

López D (2016) L'agricultura i l'alimentació dels habitants de Sant Jaume a través de les análisis carpològiques. In: García D, Gracia F, Moreno I (eds) L'assentament de la primera edat del ferro de Sant Jaume. Universitat de Barcelona, Barcelona, pp 355-367

López D, Asensio D, Jornet R, de Morer J (2015) La Font de la Canya. Guia arqueològica. Institut d'Estudis Penedesencs, Vilafranca del Penedès

López D, Buxó R, Garcia D, Moreno I (2011) Noves Aportacions Sobre Agricultura i Alimentació Durant La Primera Edat Del Ferro a Catalunya: Dades de l'assentament de Sant Jaume (Alcanar, Montsià). Pyrenae 42:77-118

Mahler-Slasky Y, Kislev ME (2010) Lathyrus consumption in late Bronze and iron age sites in Israel: an Aegean affinity. J Archaeol Sci 37:2,477-2,485. https://doi.org/10.1016/j.jas.2010.05.008

Mishra SK, Sharma B, Sharma SK (2007) Genetics and cytogenetics of lentil. In: Yadav S, McNeil D, Stevenson PC (eds) Lentil: An Ancient Crop for Modern Times. Springer, Dordrecht, pp 187-208 Montes-Moya E (2014) Las prácticas agrícolas en la Alta Andalucía a través de los análisis carpológicos (Desde la Prehistoria Reciente al S. II d.n.e.). Dissertation, Universidad de Jaén, Jaén

Mora A (2017) Irrigación y secano en el Mediterráneo Occidental (III-I Milenio A.N.E.): Un estudio isotópico. Dissertation, Universidad de Granada, Granada

Newton C, Lorre C, Sauvage C, Ivorra S, Terral J-F (2014) On the origins and spread of Olea europaea L. (olive) domestication: evidence for shape variation of olive stones at Ugarit, Late Bronze Age, Syria—a window on the Mediterranean Basin and on the westward diffusion of olive varieties. Veget Hist Archaeobot 23:567-575. https://doi.org/10.1007/s00334-013-0412-4

Oweis T, Hachum A, Pala M (2004) Lentil production under supplemental irrigation in a Mediterranean environment. Agric Water Manage 68:251-256. https://doi.org/10.1016/j.agwat.2004.03.013

Pagnoux C, Bouby L, Ivorra S et al (2015) Inferring the agrobiodiversity of Vitis vinifera L. (grapevine) in ancient Greece by comparative shape analysis of archaeological and modern seeds. Veget Hist Archaeobot 24:75-84. https://doi.org/10.1007/s00334-014-0482-y

Peña-Chocarro L, Zapata L (1999) History and traditional cultivation of Lathyrus sativus L. and Lathyrus cicera L. in the Iberian Peninsula. Veget Hist Archaeobot 8:49-52. https://doi.org/10.1007/BF02042842 
Purugganan MD, Fuller DQ (2011) Archaeological data reveal slow rates of evolution during plant domestication. Evolution 65:171-183

Ros J, Evin A, Bouby L, Ruas MP (2014) Geometric morphometric analysis of grain shape and the identification of two-rowed barley (Hordeum vulgare subsp. distichum L.) in southern France. J Archaeol Sci 41:568-575. https://doi.org/10.1016/j.jas.2013.09.015

Sabato D, Esteras C, Grillo O et al (2017) Molecular and morphological characterisation of the ldest Cucumis melo L. seeds found in the Western Mediterranean Basin. Archaeol Anthropol Sci 11:789-810.

https://doi.org/10.1007/s12520-017-0560-z

Sarpaki A (1992) The Paleoethnobotanical Approach: The Mediterranean Triad or is it a Quartet? In: Wells B (ed) Agriculture in Ancient Greece. Swedish Institute, Athens, pp 61-76

Shrestha R, Turner NC, Siddique KHM, Turner DW, Speijers J (2006) A water deficit during pod development in lentils reduces flower and pod numbers but not seed size. Aust J Agric Res 57:427-438. https://doi.org/10.1071/Ar05225

Tarongi M, Prats G, Alonso N (2020) The storage of pulses during the Bronze and Iron Ages in the East of the Iberian Peninsula: examining the archaeological data through the lens of ethnography. J Archeol Sci Rep 30:102174. https://doi.org/10.1016/j.jasrep.2019.102174

Terral J-F, Alonso N, Buxó i Capdevila R et al (2004) Historical biogeography of olive domestication (Olea europaea L.) as revealed by geometrical morphometry applied to biological and archaeological material. J Biogeogr 31:63-77. https://doi.org/10.1046/j.0305-0270.2003.01019.x

Terral J-F, Newton C, Ivorra S et al (2012) Insights into the historical biogeography of the date palm (Phoenix dactylifera L.) using geometric morphometry of modern and ancient seeds. J Biogeogr 39:929-941. https://doi.org/10.1111/j.13652699.2011.02649

Terral J-F, Tabard E, Bouby L etal (2010) Evolution and history of grapevine (Vitis vinifera) under domestication: new morphometric perspectives to understand seed domestication syndrome and reveal origins of ancient European cultivars. Ann Bot 105:443-455. https://doi.org/10.1093/aob/mcp298

Toker C, Yadav SS, Solanki IS (2007) Mutation breeding. In: Yadav S, McNeil D, Stevenson, PC (eds) Lentil: An Ancient Crop for Modern Times. Springer, Dordrecht, pp 209-224

Ucchesu M, Orrù M, Grillo O, Venora G, Usai A, Serreli PF, Bacchetta G (2015) Earliest evidence of a primitive cultivar of Vitis vinifera L. during the Bronze Age in Sardinia (Italy). Veget Hist Archaeobot 24:587-600. https://doi.org/10.1007/s00334-014-0512-9

Valamoti SM, Moniaki A, Karathanou A (2011) An investigation of processing and consumption of pulses among prehistoric societies: archaeobotanical, experimental and ethnographic evidence from Greece. Veget Hist Archaeobot 20:381-396. https://doi.org/10.1007/s00334-011-0302-6

Wallace M, Bonhomme V, Russell J et al (2018) Searching for the Origins of Bere Barley: A Geometric Morphometric Approach to Cereal Landrace Recognition in Archaeology. J Archaeol Method Th 26:1,1251,142. https://doi.org/10.1007/s10816-018-9402-2

Zohary D, Hopf M (1973) Domestication of Pulses in the Old World: Legumes were companions of wheat and barley when agriculture began in the Near East. Science 182:887-894 
Zohary D, Hopf M, Weiss E (2012). Domestication of Plants in the Old World: The origin and spread of domesticated plants in Southwest Asia, Europe, and the Mediterranean Basin. Oxford University Press,

Oxford 


\section{Figure captions}

Fig. 1 Location of the site of Font de la Canya in the Northeast of the Iberian Peninsula

Fig. 2 Example of photographs of seeds and the positioning of the distance measurements in red. Top: ventral and lateral view of Lens culinaris. Medium: ventral and lateral view of a Lathyrus sativus/cicera. Bottom: ventral and lateral view of a Vicia faba

Fig. 3 Example of the outline of a seed transformed into $\mathrm{x}$ and $\mathrm{y}$ coordinates. The red points correspond to the landmarks of the ventral and lateral views

Fig. 4 Boxplots depicting the logarithmic values of length, width and thickness of the three species under study

Fig. 5 PCA (top) and LDA (bottom) based on distance measurements (left), outline analysis (middle) and the combination of the two (right)

Fig. 6 Boxplot comparing the length and the first component of outline shape of lentils from the different chronological phases from the site of Font de la Canya

Fig. 7 Boxplot comparing the length of the different samples according to chronological phase. It is noteworthy that samples $0002,0006,0019$ and 0020 reveal a very similar distribution

Fig. 8 Visual comparison of the differences between the superimposed ventral (top) and lateral (bottom) views of the three species under study. Red colour corresponds to the taxon of the rows and blue colour to the taxon of the columns

Table 1 Correspondence between the samples, stratigraphic unit (SU), silo number and chronology. EIA: Early Iron Age (625-575 BP), EI: Early Iberian (550-450 BP), MI: Middle Iberian (400-200 BP)

Table 2 Minimum, mean, maximum and standard deviation values for each species and variable

Table 3 Comparison of the archaeobotanical identification of the seed (rows) with LDA morphometric identification (columns). Listing of the values of the results of the LDA of distance measurements, outline shape and the combination of the previous two. Left: the number of seeds with a posterior probability of $50 \%$ or greater chance of matching the statistical pattern. Right: the number of seeds with a posterior probability of $90 \%$ or more chance of matching 